\title{
PENGARUH FREKUENSI, DURASI, DAN INTENSITAS MENGGUNAKAN FACEBOOK TERHADAP PENDIDIKAN KARAKTER ANAK DI SEKOLAH PELANGI KRISTUS
}

\author{
Kartika Bayu Primasanti \\ Program Studi Ilmu Komunikasi, Fakultasa Ilmu Komunikasi, Universitas Kristen Petra \\ Jalan Siwalankerto 121-131, Surabaya 60236, INDONESIA \\ E-mail: primasanti@petra.ac.id
}

\begin{abstract}
ABSTRAK
Relasi antara media dan anak-anak telah lama menjadi obyek yang menarik dalam kajian media. Semakin berkembangnya teknologi media, semakin beragam pula problematika dalam kehidupan anak-anak terjadi. Secara lebih spesifik, penelitian ini berupaya menggambarkan relasi media tersebut terhadap pendidikan karakter anak yang saat ini juga menjadi fokus pendidikan di Indonesia. Pendekatan kuantitatif digunakan untuk mencari, mengolah, serta memaparkan data sehingga menggambarkan hubungan penggunaan media dengan pendidikan karakter ini. Penelitian ini akan dilakukan dengan secara survey kepada siswa-siswi community homeschooling, Pelangi Kristus, sebuah sekolah yang mengutamakan pendidikan karakter dalam kurikulumnya. Hasil penelitian menunjukkan tidak adanya pengaruh baik secara simultan maupun parsial antara frekuensi, durasi, dan intensitas penggunaan Facebook terhadap pendidikan karakter di sekolah Pelangi Kristus. Baik pengaruh positif maupun negatif tidak tampak dipicu oleh situs jejaring social ini. Meskipun ketersediaan akses pada Facebook baik koneksi internet maupun varian gadget sangat baik, responden belum dapat mengambil manfaat dari Facebook kecuali untuk bermain game. Perlu integrasi kurikulum pendidikan karakter dengan media literasi untuk mengoptimalkan penggunaan Facebook secara positif oleh siswa-siswi di Sekolah Pelangi Kristus ini.
\end{abstract}

Kata kunci: Pengaruh; facebook; pendidikan karakter.

\begin{abstract}
The relationship between media and children has been an intriguing issue in media studies. When media technology develops, problems regarding children's lives raise. Particularly, this research study depicted the relation of media and character education, which became a focus in Indonesia's education system. The researcher used quantitative approach to find, analyze, and present data to picture the connection of media and character education. This research study has been done by conducting a survey to students in Pelangi Kristus, a school that has been known as one of those which implement character education in its curriculum. The research study showed that there was no influence between frequency, duration, and intensity of using Facebook and character education in Pelangi Kristus school, both in negative and positive aspect. Even though there was internet access availability and variety of gadgets students owned, they were not beneficial for the students, except for entertaining themselves such as playing game. Thus, there should be a media literacy to help students understand the maximum benefit of using Facebook in Pelangi Kristus.
\end{abstract}

Keywords: Influence; facebook; character education.

\section{PENDAHULUAN}

Teori Kultivasi dari George Gebner menjelaskan perubahan perilaku yang disebabkan oleh terpaan media secara terus-menerus, bertahap dan terakumulasi (Littlejohn, 2002). Semakin sering seseorang, dalam hal ini anak-anak, diterpa oleh media tertentu, maka potensi perubahan perilakunya semakin besar. Yang menarik, sejak kemunculannya hingga saat ini, teori kultivasi cenderung dikaji pada penelitian media televisi berkaitan dengan aktivitas terpaannya. Namun, penelitian ini mengadaptasi teori tersebut dalam penelitian media baru- - tentu dengan aktivitas terpaan yang berbeda-dengan harapan dapat menguji keandalan teori ini untuk diaplikasikan seturut perkembangan teknologi yang mengiringi perkembangan kajian komunikasi, khususnya pada Facebook.

Bertahun-tahun bangsa indonesia berjuang mewujudkan pendidikan karakter yang berhasil bagi sumber daya manusianya. Ironisnya, saat perkembangan media dan teknologi semakin kompleks, lembagalembaga pendidikan justru lebih tertarik pada pe- 
ngembangan kemampuan penguasaan ilmu pengetahuan dan teknologi. Konsekuensinya, lembaga pendidikan saat ini diharapkan dapat berkontribusi lebih besar dalam meningkatkan kemampuan suatu bangsa untuk penguasaan ilmu pengetahuan dan teknologi (Yayasan Jati Diri Bangsa, 2011, p. 10). Perkembangan media dan teknologi kemudian mengurangi perhatian lembaga pendidikan pada pengembangan pendidikan karakter.

Pada tulisan sebelumnya, Mass Media Role in Developing Character Education: A Debate (ICCE, 2011, p. 60), penulis mengkaji peran positif dan negatif media dalam mengembangkan pendidikan karakter, khususnya di Indonesia. Pembahasan menunjukkan bahwa guna mengoptimalkan potensi media dalam mengembangkan pendidikan karakter, perlu persiapan pada sumber dayanya terlebih dahulu yang salah satunya dapat berwujud media literacy. Pengaruh penggunaan media terhadap pendidikan karakter harus diuji, khususnya pada sekolah yang telah melek media.

Sampai saat ini, Facebook memiliki kepopuleran yang luar biasa di kalangan anak-anak remaja atau para siswa. Uniknya, pengguna situs jejaring social ini bukan hanya dari kalangan dewasa (di atas 17 tahun) seperti yang menjadi pra syarat untuk membuat akun Facebook, namun juga anak-anak di bawah 17 tahun. Bahkan, sebuah kampanye yang berlangsung di Inggris, dan digelar sebagai bagian dari hari Keamanan Internet Uni Eropa (EU Internet Safety Day) yang digerakkan olehh $U K$ Council for Child Internet menargetkan sasaran mereka pada anak-anak usia 5-7 tahun (BBC \& CEOP, 2011, http://ictwatch.com).

Jika dicermati, pemfungsian Facebook dengan tepat sesungguhnya menghasilkan konsekuensi positif. Seperti yang dialami oleh Muhamad Yahya Harlan yang berusia 13 tahun, seorang pencipta situs ala Facebook di Indonesia. Siswa kelas 7A Sekolah Alam Bandung, Jawa Barat ini menamai situs ciptaannya dengan salingsapa.com. Hal ini menjadi contoh bahwa jika seseorang anak telah melek media, Facebook justru menjadi inspirasi untuk berkarya (Latief, 2011, http://edukasi.kompas.com). Namun, lebih banyak konsekuensi negatif dicatat dalam pemberitaan media, misalnya kompas.com yang beberapa kali mencatat pemberitaan dengan judul "Facebook Memicu Pernikahan Dini", "Tiga Siswi Dikeluarkan karena Status Facebook", "Dikeluarkan Sekolah Gara-Gara Facebook", "Kepribadian Narsistik dan Facebook" (Mikail \& Candra, 2011, http://health.kompas.com). Menurut psikolog anak,
Rose Mini, Facebook sebenarnya sudah menerapkan peraturan yang tepat, yakni bahwa pengguna Facebook adalah mereka yang telah berusia 17 tahun. Dengan demikian Facebook sebenarnya bukanlah konsumsi anak-anak SD ataupun SMP. Kenyataanya, banyak juga anak-anak di bawah usia 17 tahun menjadi user aktif pada situs ini. Menurut Rose Mini, anak-anak usia SD dan SMP seharusnya menjalin hubungan nyata bukan melalui dunia maya (Mikail \& Candra, 2011, http://health.kompas.com).

Beberapa penelitian terdahulu yang memfokuskan kajiannya pada media facebook dan pendidikan telah dilakukan oleh Skerrett (2010). Penelitian ini mengkaji kemanfaatan facebook pada proses belajar mengajar guru dengan siswa. Penelitian ini memunculkan wacana bahwa facebook dapat menjadi third space atau ruang ketiga untuk proses belajar mengajar ini. In higer education setting, Gutschmidt (2012), melalui penelitiannya, mengajukan gagasan bahwa facebook dapat digunakan dalam seting pendidikan dengan pendekatan tertentu. Sedangkan Hilscher (2013) melakukan penelitian yang menjelaskan bahwa facebook adalah sebuah komunitas belajar. Beberapa penelitian ini menunjukkan bahwa manfaat facebook dalam dunia pendidikan telah menjadi fokus kajian dari berbagai perspektif. Tetapi, penelitian dalam konteks pendidikan dasar serta kearifan lokal Indonesia perlu terus menerus dikembangkan.

Melihat dualisme peran Facebook dalam kehidupan anak-anak ini menggelitik peneliti untuk melihat kaitan antara penggunaan Facebook dengan pendidikan karakter di sekolah. Di Surabaya, salah satu sekolah yang menerapkan pendidikan karakter dalam kurikulum dan kegiatannya adalah Sekolah Pelangi Kristus (www.pelangikristus.or.id). Meskipun pendidikan karakter menjadi basis pengajaran di sekolah, berdasarkan observari awal di sekolah Pelangi Kristus, tidak dapat dihindari bahwa anak-anak di bawah usia 13 tahun pun telah menggunakan Facebook. Jika pada akhirnya ditemukan bahwa pendidikan karakter di sekolah ini baik, maka apakah Facebook memiliki pengaruh atasnya, ataukah sebaliknya.

Dalam kajian ini, peneliti akan melakukan penelitian mengenai bagaimana pengaruh frekuensi, durasi, dan intensitas menggunakan Facebook terhadap pendidikan karakter di Sekolah Pelangi Kristus. Penelitian ini akan ditujukan bagi siswa-siswi level 7 level 12 (kelas 1 SMP sampai 2 SMA) karena menurut pemaparan, anak-anak di usia 11-16 tahun adalah kelompok usia yang memiliki akses yang tidak 
terbatas pada internet. Selain itu, usia ini adalah kelompok yang sangat membutuhkan lebih banyak pengalaman dan kebebasan (Mengenalkan Internet di Usia Dua hingga 12 Tahun, 2008, dalam http:// ictwatch.com/internetsehat/2008/12/29).

Dengan pendekatan kuantitatif, peneliti menguji hipotesa teori kultivasi dengan regresi berganda, yakni apakah jika frekuensi, durasi, dan intensitas penggunaan suatu media tinggi maka potensi perubahan perilaku user pun semakin nyata.

Tujuan

a. Menunjukkan tingkat keterpengaruhan antara frekuensi, durasi, dan intensitas terhadap pendidikan karakter anak

b. Mengidentifikasi faktor lain yang mempengaruhi pendidikan karakter selain media

\subsection{Manfaat Penelitian}

Perhatian penelitian-penelitian berkaitan dengan media baru sejauh ini terletak pada media baru itu sendiri dan konsekuensinya pada user. Diperlukan beragam kajian yang mengangkat konteks tertentu, misalnya pendidikan, sebagai seting mengurai konsekuensi media baru tersebut. Bidang pendidikan, khususnya pendidikan anak sangat perlu dijadikan latar dalam kajian media baru karena kemampuannya untuk selalu terkoneksi dengan teknologi. Maka, pendidikan dan media sesungguhnya dua bidang yang tidak dapat dipisahkan. Dalam konferensi The First International Conference on Character Education yang diadakan di Universitas Negeri Yogyakarta pada 9-11 November 2011 lalu menunjukkan bahwa perhatian sebagian akademisi dan penggiat pendidikan karakter di Indonesia belum sampai pada melihat konsekuensi media baru. Beberapa kajian yang dipaparkan berkaitan isu-isu aplikasi pendidikan karakter, peran guru dan keluarga dalam pendidikan karakter atau penggunaan media bermain, peran kultur lokal. Kajian ini ingin menjadi salah satu stimulus untuk mewacanakan pentingnya mengetahui relasi media, khususnya media baru, dan pendidikan karakter dalam konteks pendidikan di Indonesia.

1. Manfaat Akademis

Menjadi referensi untuk menunjukkan relevansi Teori Kultivasi dalam kajian media baru.

2. Manfaat Praktis

Sebagai referensi untuk mewacanakan pentingnya mengetahui relasi media, khususnya media baru, dan pendidikan karakter dalam konteks pendidikan di Indonesia.

3. Manfaat Sosial

Manfaat sosial dari penelitian ini adalah hadirnya sebuah kajian yang akan membantu sekolah mengembangkan penggunakan media baru untuk meningkatkan pendidikan karakter sebagai capaian pembelajaran mereka. Selain itu, bagi orang tua siswa, penelitian ini memberikan gambaran hubungan anak dengan media baru yang semakin hari semakin dekat karena perkembangan teknologi. Dengan demikian, baik institusi pendidikan maupun keluarga dapat bersikap antisipatif terhadap dampak buruk penggunaan media baru dan bersikap kritis konstruktivis terhadap pengembangannya bagi pendidikan anak.

\section{TINJAUAN PUSTAKA}

Teori Kultivasi dan Perkembangannya pada Media Baru. Sebelumnya, teori kultivasi menjelaskan bahwa terpaan media televisi mempengaruhi bagaimana seseorang berpikir mengenai realitas sosial (Littlejohn, 2002). Teori ini berfokus pada perubahan perilaku yang disebabkan oleh terpaan media secara terus-menerus, bertahap dan terakumulasi. Gerbner membagi pemirsa dalam dua kategori, yaitu heavy TV viewer dan light TV viewer, heavy viewer cenderung beranggapan bahwa relitas sosial yang ada sesuai dengan apa yang ditampilkan oleh media. Heavy TV viewer cenderung berpikir bahwa kekerasan dan tindak kriminalitas yang terjadi sangat tinggi, tidak sesuai dengan realitas sosialnya (Sparks, 2006, p. 151).

Gerbner merangkum pandangannya bahwa pelajaranpelajaran yang kita pelajari secara berulang-ulang dari televisi sejak masa pertumbuhan pada akhirnya menjadi dasar dari cara pandang yang lebih luas (Sparks, 2006, pp. 151-152). Dari beberapa penelitian yang dilakukan Gerbner dan koleganya menyatakan dua proses yang menunjukkan kultivasi media, mainstreaming dan resonance. Mainstreaming terjadi saat orang-orang dari kelompok yang berbeda menerima terpaan media yang sama, Gerbner menyatakan bahwa saat orang-orang dari kelompok yang berbeda menerima terpaan yang sama, perbedaan yang ada di antara kelompok-kelompok tersebut menjadi semakin sedikit. Proses yang ke dua, resonance terjadi saat lingkungan menyerupai situasi yang tergambar di televisi, dampak kultivasinya menjadi semakin kuat (Sparks, 2006, p. 152).

Pada media baru, misalnya yang berwujud situs jejaring social (Facebook, twitter, dll), pola-pola tertentu justru semakin kentara. Misalnya pola grafis, warna, tulisan, karakter, page, dll. Hal ini memungkinkan prinsip yang pertama dari teori kultivasi, yakni adanya pola-pola tertentu yang terus menerus 
diterpakan. Lebih jauh, media baru menyediakan interaksi antara user dengan user atau user dengan komputer. Everett dan Caldwell mencatat, "an important part of digital media culture is bound up with the idea of interactivity and expectations for its functionality" (2003, p. 7). Jadi, pola-pola yang terbentuk pun bukan sekadar ciptaan dari produsen tertentu, melainkan, user dapat membuat polapolanya sendiri. Dalam situs jejaring Facebook, misalnya, user dapat membuat status, note, logo, symbol, dll, yang membuat mereka mudah dikenali oleh user lain.

\subsection{Media Baru dan Anak-Anak}

Dualisme yang paling poluler dalam diskusi tentang media baru, atau internet, adalah: apakah internet menjadi instigator atau konsekuensi yang paling nyata dari sebuah perubahan sosial: atau internetlah yang menyebabkan perubahan social tersebut. Apapun jawabannya, yang jelas internet selalu membawa konsekuensi tertentu, apalagi untuk anakanak. Berbagai kasus telah dipaparkan dalam pendahuluan mengenai bagaimana internet berkonsekuensi positif dan negative untuk anak-anak. Menjelaskan proses muncul dan antisipasi konsekuensi ini pun menjadi aktivitas yang tidak ada habisnya. For it also the case that almost every question ever asked about children and young people - how they learn, play, interact, participate, encounter risk - has also been asked of the relation between childhood and internet (Livingstone, 2009, p. $1)$.

\subsection{Internet dan Pendidikan Karakter}

Dalam tulisan sebelumnya (Primasanti, 2011, p. 60), peneliti telah menyusun kajian pustaka mengenai media dan problematikanya dalam pendidikan karakter. Pendidikan karakter menjadi isu yang menarik selama perkembangan media. Starker's (1989) telah mencatat bahwa kajian mengenai media yang berkonsekuensi negatif terhadap anak muda telah banyak dilakukan selama 75 tahun terakhir (Kirsh, 2010, p. 2). Menurut kajian yang dilakukan oleh Hancox, anak-anak yang berusia 5-15 tahun adalah target yang potensial untuk dipengaruhi oleh media. Dan bagian dari seorang anak yang paling menarik untuk disasar media adalah karakternya.

Fitri (2012, p. 20) menyebutkan bahwa scara etimologi, istilah karakter berasal dari bahasa Latin, character yang antara lain berarti watak, tabiat, sifat- sifat kejiwaan, budi pekerti, kepribadian dan akhlak. Secara terminologi, karakter diartikan sebagai sifat manuasia pada umumnya yang bergantung pada faktor kehidupannya sendiri. Karakter adalah sifat kejiwaan, akhlak, atau budi pekerti yang menjadi cirri khas seseorang atau sekelompok orang. Karakter merupakan nilai-nilai perilaku manusia yang berhubungan dengan Tuhan yang Maha Esa, diri sendiri, sesame manusia, lingkungan dan kebangsaan, yang terwujud dalam pik iran, sikap, perasaan, perkataan dan perbuatan berdasarkan norma-norma agama, hukum, tata karma, budaya, dan adat istiadat. Sementara, sebagai sebuah proses pendidikan, pendidikan karakter harus memuat (Mu'In, 2011, p. 290):

1. Proses pemberdayaan (empowering)

2. Proses pencerahan (enlightment)

3. Proses memberikan motivasi dan inspirasi

4. Proses mengubah perilaku

Sejak awal kemunculan pendidikan, pendidikan karakter sesungguhnya merupakan sesuatu yang niscaya. Mu'in (2011, p. 297) mengutip pernyataan John Dewey (1916) yang mengatakan, "Sudah merupakan hal lumrah dalam teori pendidikan bahwa pembentukan watak merupakan tujuan umum pengajaran dan pendidikan budi pekerti di sekolah". Pada awal perkembangannya, di dunia barat, pendidikan karakter memang merupakan jawaban atas kekeringan yang dihasilkan oleh sistem pendidikan yang bersifat positivistik yang membuat jiwa manusia kering akibat adanya industrialisasi yang menggeser nilai-nilai spiritual dan kemansiaan (Mu'In, 2011, p. 2298). Pada jaman Yunani kuno, pendidikan karakter dibangun berlandaskan pesimisme atas ukuran-ukuran moral dan etika; pada jaman Abad Pertengahan, pembangunan karakter diarahkan pada pemujaan manusia; di era modern, pendidikan karakter diupayakan untuk menciptakan ruang dan waktu yang kondusif bagi perkembangan anak.

Fitri (2012, p. 36) mencatat beberapa problem pendidikan karakter:

1. Harus melibatkan banyak pihak, orang tua, guru, lingkungan, dan masyarakat secara umum.

2. Karakter negative sudah menyebar, bahkan secara sadar atau tidak melekat pada diri anak secara sistematis.

3. Pandangan masyarakat yang menginginkan mutu instan serta budaya materialism akan sangat menyulitkan upaya pendidikan karakter ini.

4. Media massa bahkan internet yang memublikasikan hal-hal negative secara massif dan terus menerus memberikan isi yang tidak mendidik.

5. Masyarakat yang semakin individualistik. 
Saat ini, salah satu musuh terbesar pendidikan karakter, sekaligus musuh terbesar anak-anak adalah internet dengan konten seks seperti predator yang menunggu mereka pada chatroom. Contemporary, one of the greatest threats in children appears to be from the internet, with sexual predators lurking in chat rooms meant for children and pornography merely a click away (Kirsh, 2010, p. 2). Riset dalam bidang ini telah dilakukan berulang kali. Namun demikian, kompleksnya proses yang terjadi dalam internet membuat kajian ini tidak pernah bisa berhenti dilakukan. Efek yang begitu nyata atas penggunaan internet pada anak-anak menjadi stimulus untuk melakukan beragam kajian.

Dampak negatif dari penggunaan internet pada anakanak dalam table 2.1. sangat erat kaitannya dengan prinsip-prinsip pendidikan karakter yang dipaparkan dalam Character Education Partnership's Eleven Principle of Effective Character Education, yakni (Lickona, T., Schaps, E., \& Lewis, C, 2003 dalam Battistich, 2002).

Jika ekses negatif dari penggunaan internet ternyata berkaitan dengan keberhasilan aplikasi pendidikan karakter di sekolah, maka penting untuk merunut dan menghitung secara spesifik pengaruhnya. Jalinan antara pendidikan karakter dan penggunaan media baru ini akan diuji dalam penelitian ini dengan teori kultivasi sebagai acuannya. Paradigma positivistic membantu pengujian hipotesis menjadi pandangan general mengenai relasi penggunaan media dengan pendidikan karakter di Indonesia.

\section{METODE PENELITIAN}

\subsection{Definisi Konseptual}

Di dalam Teori Kultivasi, dikenal tiga konsep untuk menjadi ukuran terpaan sebuah media pada seorang individu, yakni: frekuensi, durasi, intensitas. Frekuensi merupakan banyaknya (dihitung dengan kali) orang mengakses suatu media atau isi media tertentu. Durasi berbicara mengenai lamanya, atau panjangnya waktu yang dibutuhkan seseorang untuk mengakses media tertentu. Intensitas merupakan sebuah konstruk mengenai intensi atau kedalaman seseorang mengakses media tertentu, yang dapat diukur dengan tingkat perhatian seseorang tersebut pada media atau content yang diaksesnya. Sedangkan konsep pendidikan karakter, yang merupakan variabel dependen dalam penelitian ini dijelaskan secara umum sebagai pendidikan yang mengarahkan siswa untuk memiliki ruang dan waktu yang cukup bagi perkembangan kejiwaan, akhlak, atau budi pekerti yang menjadi cirri khas seseorang atau sekelompok orang.

\subsection{Definisi Operasional}

Penelitian regresi berganda ini memerlukan pengoperasian empat variabel yang akan diteliti. Variabel ini merupakan operasionalisasi dari Teori Kultivasi yang digunakan sebagai grand theory dalam penelitian ini, di mana variabel X1, X2, dan X3 sebagai variabel yang menunjukkan pengukuran terpaan, sedangkan variabel $\mathrm{Y}$ mereupakan variabel yang menjadi akibat dari terpaan. Variabel independen atau variabel yang mempengaruhi, yang selanjutnya disebut Variabel X, terdiri dari: Variabel Frekuensi (X1), Variabel Durasi (X2), Variabel Intensitas (X3). Dengan mempertimbangkan jam belajar siswa di sekolah (ketika belajar tidak diperbolehkan membawa handphone), dan perkiraan jam tidur anak maksimal pukul 24.00 WIB, serta alokasi waktu belajar di rumah, maka sisa waktu yang para siswa ini miliki untuk melakukan aktivitas lain kira-kira 6 jam. Sebagai variabel yang dipengaruhi atau variabel dependen (Variabel Y), variabel pendidikan karakter dioperasionalkan berdasarkan 11 prinsip pendidikan karakter menurut Lickona, Schaps, \& Lewis (2003, dalam Battistich, 2002).

Hipotesis Nol/ Null (Hipotesis awal):

H01 : Tidak ada pengaruh antara frekuensi menggunakan facebook terhadap pendidikan karakter

H02: Tidak ada pengaruh antara durasi menggunakan facebook terhadap pendidikan karakter

H03: Tidak ada pengaruh antara intensitas menggunakan facebook terhadap pendidikan karakter

Hipotesis Alternatif/ Ha/ H1:

H01 : Ada pengaruh antara frekuensi menggunakan facebook terhadap pendidikan karakter

H02: Ada pengaruh antara durasi menggunakan facebook terhadap pendidikan karakter

H03: Ada pengaruh antara intensitas menggunakan facebook terhadap pendidikan

\subsection{Metode yang Digunakan}

Penelitian ini akan dilakukan dengan menggunakan pendekatan kuantitatif yang menurut Bryman (2004), "... describes as entailing the collection of numerical data and as exhibiting a view of the relationship between theory and research as deductive, a predilection for a natural science approach (and of positivism 
in particular), and as having an objectivist conception of social reality" (p. 62). Secara deskriptif data akan dipaparkan dengan menggunakan table distribusi frekuensi. Bryman (2004) menambahkan, "A frequency table provides the number of people and the percentage belonging to each of the categories for the variable in question. It can be used in the relation to all of the different types of variable," (p. 227). Untuk menguji analisisnya, peneliti akan menggunakan teknik analisis regresi berganda.

\subsection{Teknik Pengumpulan Data}

Pengambilan data akan menggunakan metode survey total sampling dengan menggunakan kuesioner kepada 47 orang siswa-siswi di sekolah Pelangi Kristus Level 7-12 sebagai populasi sekaligus sampel dalam penelitian ini.

\section{HASIL DAN PEMBAHASAN}

\subsection{Analisis Regresi}

Hasil analisis regresi berganda antara variabel $\mathrm{X} 1$, $\mathrm{X} 2, \mathrm{X} 3$ dengan variabel $\mathrm{Y}$. Untuk mengetahui hasil uji regresi linear berganda ini, akan dipaparkan hasil uji Regresi Linear Berganda, Uji T, Uji F (Anova), dan Koefisien Determinasi $\left(\mathrm{R}^{2}\right)$.

\subsubsection{Regresi Linear Berganda}

Analsis regresi linear berganda digunakan untuk mengukur pengaruh antara lebih dari satu variabel predictor (variabel bebas) terhadap variabel terikat.

Tabel 1. Tabel Analisis Regresi Berganda

\begin{tabular}{|c|c|c|c|c|c|c|}
\hline \multicolumn{7}{|c|}{ Coefficients(a) } \\
\hline \multirow[t]{2}{*}{$\begin{array}{l}\text { Mo- } \\
\text { del }\end{array}$} & & $\begin{array}{l}\text { Unstan- } \\
\text { dardized } \\
\text { Coeffi- } \\
\text { cients }\end{array}$ & $\begin{array}{c}\text { Standar- } \\
\text { dized } \\
\text { Coefficients }\end{array}$ & $\mathrm{t}$ & \multirow{2}{*}{\multicolumn{2}{|c|}{ Sig. }} \\
\hline & & B & Std. Error & Beta & & \\
\hline \multirow[t]{4}{*}{1} & (Constant) & 52.321 & 6.320 & & 8.278 & .000 \\
\hline & $\begin{array}{l}\text { Frekuensi } \\
\text { Menggunakan } \\
\text { FB }\end{array}$ & 1.273 & 1.887 & .111 & .675 & .505 \\
\hline & $\begin{array}{l}\text { Durasi } \\
\text { Menggunakan } \\
\text { FB }\end{array}$ & 3.695 & 2.775 & .218 & 1.332 & .192 \\
\hline & $\begin{array}{l}\text { Intensitas } \\
\text { Menggunakan } \\
\text { FB }\end{array}$ & -2.307 & 1.370 & -.278 & -1.684 & .102 \\
\hline
\end{tabular}

a Dependent Variable: Total_Y

Pada variabel bebas yang ke dua ini, nilai koefisien yang diperoleh adalah 3.695. Seperti logika sebelum- nya, angka ini menunjukkan kenaikan nilai pada variabel pendidikan karakter jika satuan durasi (X1) dinaikkan 1 satuan. Angka kenaikannya lebih tinggi dari angka kenaikan yang diakibatkan oleh variabel frekuensi. Variabel durasi atau lamanya mengakses Facebook ini bisa dikatakan memberikan dampak yang lebih terhadap variabel pendidikan karakter, dari pada frekuensi mengakses Facebook.

Berbeda dengan kedua variabel sebelumnya, variabel bebas intensitas mengakses Facebook (X3) mendapat nilai koefisien negatif dengan angka -2.307. Hal ini berarti setiap kenaikan satu satuan pada variabel intensitas justru membuat variabel pendidikan karakter turun sebesar 2.307. Hal ini sangat mungkin terjadi karena sesungguhnya siswa mengakses Facebook hanya untuk sampingan saja, bukan fokus utama. Dari jawaban responden dapat diprediksi bahwa responden ini justru lebih tertarik dan menganggap penting untuk membuka situs lain dari pada Facebook. Situs lain ini lah yang dimungkinkan lebih mendukung pendidikan karakternya. Sehingga jika responden membuka Facebook saja, tanpa membuka situs lain atau mengerjakan hal lain, justru menghambat pendidikan karakter atau dengan kata lain menurunkan nilai variabel pendidikan karakternya.

\subsubsection{Uji T}

Uji T dalam penelitian ini digunakan untuk melihat apakah setiap variabel bebas secara parsial memiliki pengaruh terhadap variabel Y. Untuk mengujinya, peneliti menggunakan derajat signifikansi 0.05 . Sehingga, jikan sig. yang didapat dari perhitungan kurang dari 0.05 maka Hipotesis alternative penelitian ini diterima, yakni bahwa variabel bebas secara parsial berpengaruh terhadap variabel terikat.

Tabel 2. Tabel Uji T

\begin{tabular}{llrl}
\multicolumn{3}{c}{ Coefficients(a) } \\
\hline Model & \multicolumn{1}{c}{$\mathrm{t}$} & Sig. \\
\hline 1 & (Constant) & 8.278 & .000 \\
& Frekuensi Menggunakan FB & .675 & .505 \\
& Durasi Menggunakan FB & 1.332 & .192 \\
& Intensitas Menggunakan FB & -1.684 & .102 \\
\hline a Dependent Variable: Total_Y & &
\end{tabular}

Dari hasil pengujian tampak bahwa secara parsial setiap variabel bebas tidak memiliki pengaruh terhadap variabel terikat. Untuk perhitungan variabel frekuensi terhadap pendidikan karakter, nilai sig yang muncul adalah 0.505 . Nilai ini tentu lebih besar dari derajat kepercayaan yang telah ditetapkan, yakni 0.05. 
Hasilnya, $\mathrm{H} 1$ ditolak dan $\mathrm{H} 0$ diterima. Untuk variabel durasi terhadap variabel pendidikan karakter, nilai sig yang diperoleh adalah 0.192 yang juga lebih besar dari derajat kepercayaan 0.05. Pada hipotesis yang ke dua ini pun, terjadi penolakan terhadap $\mathrm{H} 1$ dan penerimaan terhadap H0. Terakhir, pengujian hipotesis antara variabel intensitas dengan variabel pendidikan karakter menghasilkan nilai sig 0.102 yang juga lebih tinggi dari pada 0.05 . Secara otomatis, pada hipotesis ini pun, $\mathrm{H} 1$ ditolak dan $\mathrm{H} 0$ diterima. Secara keseluruhan dapat disimpulkan bahwa secara parsial, masing-masing variabel bebas tidak memiliki pengaruh terhadap variabel terikat.

Responden di sekolah Pelangi Kristus telah menerima pendidikan karakter sejak usia dini (pre school). Seperti yang diungkapkan Mu'In pendidikan karakter harus memuat (Mu'In, 2011, p. 290):

1. Proses pemberdayaan (empowering)

2. Proses pencerahan (enlightment)

3. Proses memberikan motivasi dan inspirasi

4. Proses mengubah perilaku

Durasi pendidikan yang telah ditempuh begitu lama (minimal 7 tahun) oleh siswa di sekolah Pelangi Kristus ini telah cukup memberikan filter yang menindikasi penolakan pada keterpengaruhan media baru, khsususnya Facebook ini terhadap para siswanya. Lagipula, dengan kegiatan - baik dalam kurikulum maupun di luar kurikulum-yang begitu beragam, membuat para siswa memiliki waktu yang terbatas untuk melakukan interaksi dalam situs jejaring sosial. Karena tidak semudah membuka buku atau menyalakan televisi, bermain dalam situs jejaring sosial ini membutuhkan energi yang lebih.

Seperti terjelaskan pada data deskriptif, lebih dari $50 \%$ responden mengakses maksimal 2 aplikasi saja dari seluruh fitur yang dimiliki Facebook, yakni untuk bermain game dan melihat profil atau berita temannya. Hal ini mengindikasikan bahwa respondenbaik dengan filter pendidikan karakternya maupun dengan proses belajar yang mensyaratkan tersitanya banyak waktu luang siswa-tidak mengalami pengaruh penggunaan Facebook. Responden dapat mengontrol penggunaan Facebook sehingga tidak menimbulkan pengaruh yang signifikan pada hasil pendidikan karakter yang mereka dapatkan di sekolah.

Sedangkan dalam penelitian sebelumnya mengenai Hubungan Penggunaan Situs Jejaring Sosial Facebook terhadap Perilaku Remaja di Kota Makasar yang dilakukan oleh Christiany Judhita (2011) menunjuk- kan adanya hubungan antara penggunaan Facebook dengan perilaku remaja. Salah satu kesimpulannya mengatakan bahwa keberadaan Facebook bahkan membuat remaja menjadi kecanduan. Hasil yang bertolak belakang ini diprediksi karena beberapa faktor pemicu, seperti sistem pendidikan karakter yang diterapkan di sekolah Pelangi Kristus yang dengan angka mean yang tergolong tinggi dalam penelitian ini cukup menjadi filter bagi para responden terhadap pengaruh Facebook. Hal lainnya adalah responden dalam penelitian ini menganggap aktivitas bermain Facebook hanya sebagai aktivitas sampingan. Dari data deksirptif variabel didapati bahwa responden yang saat mengakses Facebook benar-benar fokus hanya enam responden atau $16.7 \%$ saja. Ukuran variabel intensitas membuka Facebook didominasi oleh responden yang membuka Facebook dan membuka lebih dari 1 tab lain, yakni 14 responden atau $38.9 \%$ dan responden yang membuka Facebook dengan mengerjakan hal lain, yakni 15 responden atau $41.7 \%$. Data ini menyuratkan bahwa Facebook belum dipahami sebagai situs jejaring sosial yang dapat memberikan kemanfaatan ekonomi, edukasi, sosial, dan pengetahuan namun hanya sebagai page tertentu yang dapat dibuka sewaktu responden sedang melakukan aktivitas utama; dan berfungsi sebagai tool untuk hiburan, seperti bermain game.

\subsubsection{Uji F (Anova)}

Melengkapi uji T yang sudah dilakukan sebelumnya, Uji $\mathrm{F}$ ini digunakan untuk melihat apakah ketiga variabel bebas memiliki pengaruh yang signifikan terhadap variabel terikatnya. Apabila F hitung (derajat kepercayaan yang digunakan 0.05 ) lebih besar dari $\mathrm{F}$ tabel, maka H1 secara keseluruhan bisa diterima, yakni bahwa variabel bebas memiliki pengaruh terhadap variabel dependen.

Tabel 3. Hasil Uji Hipotesis dengan Uji F

\begin{tabular}{lrrrrll}
\multicolumn{7}{c}{ ANOVA(b) } \\
\hline \multicolumn{1}{l}{ Model } & $\begin{array}{c}\text { Sum of } \\
\text { Squares }\end{array}$ & df & $\begin{array}{c}\text { Mean } \\
\text { Square }\end{array}$ & F & Sig. \\
\hline 1 & Regression & 1.710 & 3 & .570 & 1.730 & $.181(\mathrm{a})$ \\
& Residual & 10.542 & 32 & .329 & & \\
\multicolumn{2}{l}{ Total } & 12.252 & 35 & & & \\
\hline
\end{tabular}

a. Predictors: (Constant), Intensitas Menggunakan FB, Durasi Menggunakan FB, Frekuensi Menggunakan FB

b. Dependent Variable: Mean_Total_Y

Dengan jumlah responden sebanyak $\mathrm{N}=36, \mathrm{df} 1=\mathrm{k}$ (jumlah variabel) yakni 3 ; dan df $2=\mathrm{N}-\mathrm{k}$ yakni 32 ; dan derajat kepercayaan 0.05 maka diperoleh $\mathrm{F}$ tabel 
2.87. Jika dibandingkan dengan $F$ tabel maka $F$ hitung (1.730) lebih kecil. Dengan demikian, H0 diterima, yakni secara simultan variabel bebas tidak berpengaruh terhadap variabel terikat. Seperti analisis pada bagian sebelumnya (pengaruh parsial variabel bebas terhadap variabel terikat), secara simultan pun ketiga variabel penggunaan Facebook tidak bisa menjadi determinasi keberhasilan atau kemunduran pendidikan karakter yang terimplementasi di sekolah Pelangi Kristus. Jikalau Facebook tidak memberikan pengaruh negative pada pendidikan karakter responden, baiklah facbook mengambil sisi peran positifnya karena online opportunity membuka kesempatan untuk berbagai hal seperti megnakses informasi global, social network di antara teman, hiburan, permainan, pelibatan komunitas, melek teknologi, kesehatan personal, berbagi pengalaman jarak jauh dengan orang lain (Livingstone, 2009, p. 30). Namun, keterpengaruhan ini pun tidak ditampakkan dari uji $\mathrm{F}$ yang telah dilakukan. Bahkan, responden tidak menggunakan beragam fitur yang ada pada Facebook untuk beragam keuntungan yang telah disebutkan itu. Artinya, bagi para responden, Facebook dipahami sebagai dunia game yang bisa membua mereka sejenak rilex dari segala aktivitas mereka tanpa harus beraktivitas secara sosial lagi melalui fitur jejaring sosialnya.

\subsubsection{Koefisien Determinasi $\left(\mathbf{R}^{2}\right)$}

Koefisien determinasi $\mathrm{R}^{2}$ digunakan untuk mengetahui hubungan dari beberapa variabel dalam penelitian ini. Koefisien determinasi akan menjelaskan seberapa besar perubahan suatu variabel bisa dijelaskan oleh variabel yang lainnya.

Dari uji statistic ini diketahui bahwa Koefisien determinasi atau R Square adalah 0.140. Angka ini sangat jauh dari angka 1 yang menunjukkan korelasi yang sempurna. Jadi dapat dikatakan bahwa penggunaan Facebook sesungguhnya tidak berkorelasi dengan pendidikan karakter di sekolah ini. Dengan kenihilan hubungan ini, penggunaan Facebook sebagai media - meskipun tidak memberikan pengaruh negative pada perkembangan pendidikan karakter responden - juga tidak memberi pengaruh positif padanya.

\subsection{Interpretasi}

Melalui pengamatan di lapangan, survey, dan interview yang dilakukan, didapati bahwa responden penelitian ini adalah siswa dengan tingkat ekonomi menengah ke atas (dengan orang tua sebagai pendeta, guru, pengusaha), yang telah mengenyam pendidikan karakter di sekolah Pelangi Kristus minimal 7 tahun. Ketersediaan koneksi internet dan varian gadget yang digunakan mayoritas responden memberikan keleluasaan untuk mengakses jejaring sosial, Facebook, tepat pada saat mereka berada di usia yang memiliki akses yang tidak terbatas pada internet. Selain itu usia ini adalah usia yang sangat membutuhkan lebih banyak pengalaman dan kebebasan.

Ternyata, keleluasaan ini tidak dapat digunakan dengan potensial oleh responden dengan melihat bahwa frekuensi, durasi, dan intensitas mengakses jejaring sosial ini cenderung rendah. Apakah ini karena kuatnya pendidikan karakter yang telah diimplementasikan melalui kurikulum di sekolah ini sejak lama atau karena responden belum memahami benefit dari situs jejaring sosial ini, merupakan hal yang perlu dijelaskan secara eksploratif pada penelitian lanjutan. Penelitian ini justru ingin befokus pada kemungkinan pendidikan media literacy yang masih rendah yang membuat meskipun penggunaan Facebook tidak berdampak negatif, tidak juga berdampak positif. Hasil penelitian ini tidak mengkonfirmasi keandalan cultivation theory dalam penggunaan jejaring sosial, khususnya Facebook terhadap pendidikan karakter. Ada beberapa faktor yang mempengaruhi pendidikan karakter yang tidak bisa dijelaskan dengan pengaruh penggunaan Facebook. Karena berbeda dengan media tradisional, seperti televisi, internet, khususnya jejaring sosial membutuhkan media literasi yang cukup tinggi.

Media literasi atau melek media merupakan sebuah pendangan kritis, partisipatif, dan keterlibatan yang kreatif terhadap semua bentuk media dan komunikasi (Livingstone, 2009, p. 198).

Dengan media literasi, seharusnya responden dapat memanfaatkan pengaruh positif Facebook untuk berbagai kepentingan pengembangan diri mereka. Dengan memahami Facebook sebagai sebuah alat, responden dapat menggunakannya untuk mengakses, menganalisis, dan mengevaluasi kekuatan informasi, gambar, tulisan, suara dan pesan dalam yang berguna proses pendidikan mereka.

\section{KESIMPULAN}

Ketiga hipotesis dalam penelitian ini telah terjawab, yakni bahwa secara simultan maupun parsial tidak ada pengaruh antara frekuensi, durasi, dan intensitas penggunaan Facebook terhadap pendidikan karakter siswa di sekolah Pelangi Kristus. Keterjaminan dan 
ketercukupan akses internet yang dimiliki oleh responden tidak menjamin bahwa penggunaan situs jejaring sosial ini menjadi tinggi seperti yang dihasilkan oleh penelitian sebelumnya yang dikutip dalam riset ini. Kepadatan kurikulum dan kegiatan responden di dalam maupun di luar sekolah serta dampak pendidikan karakter yang sudah terlihat bisa saja menjadi argument penggunaan Facebook oleh responden yang cenderung rendah.

Selain ironi mengenai penggunaan yang rendah di tengah ketersediaan akses internet yang cukup, penelitian ini juga menemukan bahwa responden tidak terpengaruh oleh Facebook secara negative maupun positif karena belum dapat mengambil opportunity dari jejaring sosial ini dengan tepat. Mayoritas responden menggunakan Facebook laiknya situs game online, untuk mengisi waktu sembari mengerjakan pekerjaan lainnya. Mengenai hal ini, literasi media menjadi isu yang penting untuk diangkat.

\section{DAFTAR REFERENSI}

Anak Makin melek Internet? Berikut Panduan yang Wajib Dicatat. (2011). www.ictwatch.com. Diunduh dari http://ictwatch.com/internetsehat/ 2011/07/20/anak-makin-melek-internet-berikutpanduan-wajib-dicatat.

Battistich, V. (2002). Character Education, Prevention, and Positive Youth Development. St Louis: University of Missouri.

BBC dan CEOP. 2010. Kampanye Keamanan Internet Kini Menyasar Anak Kecil diunduh dari http://ictwatch.com/internetsehat/2010/02/19/ka mpanye-keamanan-internet-kini-menyasaranak-kecil.

Everett, A., Caldwell, T. (2003). New Media: Theories and Practices of Digitextuality. UK: Routledge.

Fitri, Z. (2012). Pendidikan Karakter Berbasis Nilai dan Etika di Sekolah. Jogjakarta: Ar Ruzz Media

Gutschmidt, A. M. (2012). A case study investigating the use of facebook as a learning management system in higher education (Order No. 3538269). Available from ProQuest Dissertations \& Theses Global. (1346025021). Retrieved from http://search.proquest.com/docview/1346025021 ?accountid=8624.
Hilscher, J. (2013). A case study examining how students make meaning out of using facebook as a virtual learning community at a midwestern university (Order No. 3566011). Available from ProQuest Dissertations \& Theses Global. (1416379218). Retrieved from http://search. proquest.com/docview/1416379218?accountid= 8624.

Juditha, C. (2011). Hubungan Penggunaan Media Jejaring Sosial Facebook terhadap Perilaku Remaja di Kota Makassar. Makasar: Balai Besar Pengkajian dan Pengembangan Komunikasi dan Informatika Makassar. Diunduh dari http://isjd.pdii.lipi.go.id/admin/jurnal/13111122_ 1410-3346.pdf.

Kirsh, S. (2010). Media and Youth: A Developmental Perspective. UK: Wiley Blackwell.

Latief. (2011). Wow, Anak SMP Biin Situl Ala Facebook. Diunduh dari: http://edukasi.kompas.com/ $\mathrm{read} / 2011 / 02 / 11 / 1105163 /$ Wow.Anak.SMP.Bik in.Situs.Ala.Facebook.

Littlejohn, S. (2002). Theories of Human Communication. USA: Wadsworth.

Livingstone, S. (2009). Children and The Internet. UK: Polity Press

Mengenalkan Internet di Usia Dua hingga 12 Tahun. (2008). www.ictwatch.com. Diunduh dari: http://ictwatch.com/internetsehat/2008/12/29/me ngenalkan-internet-di-usia-2-hingga-12-tahun

Mikail, B., Chandra, A. 2011. Inilah Alasan anak Harus Stop Main Facebook. Diunduh dari http://health.kompas.com/read/2011/05/05/1545 1975/Inilah.Alasan.Anak.Harus.Stop.Main.Face book

Mu'In, F. (2011). Pendidikan Karakter: Konstruksi Teoritik dan Praktik. Jogjakarta: Ar Ruzz Media

Primasanti, K. (2011). Character education. $I^{\text {st }}$ International Conference on Character Education: Proceeding. Yogyakarta: Yogyakarta State University: www.pelangi.kristus.or.id.

Selain Filter, Keluarga Berperan Penting. (2010). www.ictwatch.com. Diunduh dari: http://ictwatch.com/internetsehat/2010/02/09/selainfilter-keluarga-berperan-penting.

Sparks, G. (2006). Media Effect Research: A Basic Overview. Canada: Thompson.

Skerrett, A. (2010). Lolita, Facebook, and the Third Space of Literacy Teacher Education. Educational Studies: Journal of the American Educational Studies Association, 46(1), 67-84. 